Journal of the Royal Asiatic Society

Review Article

War, State-Building, and International Connections in Nationalist China

Helena F. S. Lopes, University of Oxford 


\section{Review Article \\ War, State-Building, and International Connections in Nationalist China}

Felix Boecking, No Great Wall: Trade, Tariffs, and Nationalism in Republican China, 1927-1945. Cambridge, MA: Harvard University Press, 2017.

Shuge Wei, News Under Fire: China's Propaganda Against Japan in the EnglishLanguage Press, 1928-1941. Hong Kong: Hong Kong University Press, 2017.

Yun Xia, Down with Traitors: Justice and Nationalism in Wartime China. Seattle and London: University of Washington Press, 2017.

In a recent survey of modern China, historian Rana Mitter noted: "The war between China and Japan may have been the single most important event to shape twentieth-century China". ${ }^{1}$ This perspective hasn't been around for very long. The relevance of China's War of Resistance against Japan (KangRi zhanzheng) has been revaluated by historians in recent years, a prime example of this being Mitter's book on the subject and the work of Hans van de Ven. ${ }^{2}$ For years, the victory of the Chinese Communist Party (CCP) in 1949 was crystallised into a crucial turning point and the Kuomintang (Nationalist Party/KMT) was seen as corrupt and ineffective, as epitomised by Lloyd Eastman's studies. ${ }^{3}$ Eastman's verdict is not entirely contradicted by some of the new scholarship, although important revisionist works have led to a reassessment of the KMT state-building efforts, in particular during their pre-war decade in power, the so-called Nanjing decade (1927-1937). Although the 'rediscovery' of the war came later in the English-language than it did in Chinese, it is undeniable that recent years have seen a growing interest in the period, both in academia and in popular culture. The three monographs under review here are, in many ways, illustrative of the best new research on the conflict. They provide comprehensive insight on the impact of

\footnotetext{
${ }^{1}$ R. Mitter, 'The War Years, 1937-1949', in Jeffrey N. Wasserstrom (ed), The Oxford Illustrated History of Modern China (Oxford, 2016), p .150.

${ }^{2}$ R. Mitter, China's War with Japan, 1937-1945: The Struggle for Survival (London, 2013); H. van de Ven, China at War: Triumph and Tragedy in the Emergence of the New China, 1937-1952 (London, 2017); H. van de Ven, War and Nationalism in China, 1925-1945 (London, 2003).

${ }^{3}$ E.g. L. E. Eastman, Seeds of Destruction: Nationalist China in War and Revolution, 1937-1949 (Stanford, 1984).
} 
the war on the Nationalists' state-building efforts in fiscal policy, propaganda, and justice. All are first monographs, springing from meticulous doctoral and post-doctoral research anchored on a plethora of new primary sources. They make important contributions to our understanding of the impact of the war in China, as well as to economic history, media studies, and legal history more broadly.

All of these books address the war period not as an isolated interregnum but very much connected to what preceded, and, sometimes, what followed it. In fact, their chronology is not the customary 1937-1945 interval. Felix Boecking's No Great Wall interprets the Kuomintang's tariff policy from 1927, with a chapter on the war years serving to assess the effect the conflict had on undoing part of the successes achieved in the Nanjing decade. Shuge Wei's News Under Fire analyses anti-Japan propaganda starting from 1928 and ends her study in 1941, effectively demonstrating how China's War against Japan was already internationalised before the start of the so-called Pacific War. Yun Xia's Down with Traitors is primarily concerned with discussing post-war justice against alleged collaborators. However, the war is central to all these monographs and their arguments and thus are worthy of particular attention to anyone interested in China's global Second World War.

\section{Tariff policy and the rise and fall of the Kuomintang party-state}

In No Great Wall Felix Boecking analyses the Nationalist government's fiscal policy from its rise to power in the wake of the Northern Expedition in 1927 until the end of the Second World War. As the author highlights from the start, tariffs, particularly over foreign trade, "were the single most important source of government revenue for the Nationalist government" (p. 1). That is, until the war with Japan started. By evaluating its impact, Boecking is also highlighting how the war contributed to the erosion of state-building by the KMT.

At the core of Boecking's study is the interplay of a nationalist domestic policy and the limitations imposed by foreign imperialism. His case study is the Chinese Maritime Customs (CMC), an institution that has attracted a considerable amount of scholarly interest. ${ }^{4}$

\footnotetext{
${ }^{4}$ Recent examples (amongst several others) include H. van de Ven, Breaking with the Past: The Maritime Customs Service and the Global Origins of Modernity in China (New York, 2014), C. Ladds, Empire Careers: Working for the Chinese Customs Service, 1854-1949 (Manchester, 2013); C. Chang, Government, Imperialism and Nationalism in China: The Maritime Customs Service and its Chinese Staff (London, 2012); R. Bickers, 'Anglo-Japanese Relations in Treaty Port China: The Case of the Chinese Maritime Customs Service, 18991941', in A. Best (ed), The International History of East Asia, 1900-1968: Ideology, Trade and the Quest for Order (London, 2010), pp. 35-56; R. Bickers, 'The Chinese Maritime Customs at War, 1941-1945', Journal of
} 
The book makes a valuable contribution to the economic history of Nationalist China by revisiting the $\mathrm{CMC}$ from a new perspective, in the context of the economic history of Republican China. It takes into account the transnational dimension of the institution, which is also reflected in the vast array of primary sources cited by the author, including archives in Britain, the United States, Germany, and China, notably the inspectorate general records in the Second Historical Archives in Nanjing.

Boecking puts forth the revisionist argument that the Nationalists fiscal policy was "successful in many areas" (p. 64) and chapters one to five detail the measure of that accomplishment. Tariff autonomy was seen as inextricable from matters of sovereignty ( $p$. 70), so regaining it was a key goal of the Nationalists. The treaties they signed with the United States, Britain, and Japan in 1928, 1929, and 1930 gave Chiang Kai-shek's government its "first major foreign-policy achievement" (p. 62).

Similarly to Hans van de Ven in his Breaking with the Past, Boecking is interested in analysing the $\mathrm{CMC}$ as a Chinese institution. In particular what the CMC meant for KMT state-building, and not so much what it meant for the foreigners who staffed it - although that is also inevitably addressed throughout No Great Wall. According to the author, the CMC were key to realising the "technocratic, modernist vision of governance" that was "central to the Nationalists' claim to political legitimacy", including its projection beyond the areas they controlled (p. 92, p. 236). This 'economic modernity' was evidenced by new technologies and administrative practices and was well illustrated by the compilation of trade statistics. These "served to reassure foreign creditors that the revenue collected by the Maritime Customs was sufficient for China to continue to meet its international obligations", and, therefore, crucial "for China to be able to secure further international loans" (p. 107).

Getting the CMC under full Chinese government power had been part of Nationalist state-building goals long before they took power in 1927, having been clearly advocated by the party's 'founding father', Sun Yat-sen (p. 69). If controlling the CMS was an imperative for the Nationalists, the book highlights how, rather than sudden complete nationalisation, gradual change via "a more consensual, negotiated approach" (p. 83), was the course taken and the root to their initial success. The author states that "the Nationalists decided to accommodate a remaining foreign presence within the Maritime Customs in the interest of stable revenue collection, meanwhile continuing the process of diminishing the foreign presence within it" (p. 29). In 1929, the appointment of Frederick Maze as inspector general 
(IG) announced the winds of change. Maze, a nephew of the influential second IG, Sir Robert Hart, was regarded as pro-Nationalist. His appointment was initially opposed by foreign diplomats and expats with China interests. He advocated the promotion of Chinese members of the Indoor Staff to higher posts. Chinese nationals had been barred from these until the 1920s (pp. 79-80). This trend would not be reversed in subsequent years, with the exception of the war period when the IG was forced by Japanese authorities to take new Japanese recruits (p. 81). Boecking posits that: "The advancement of Chinese officials to the highest ranks in the customs service was crucial to the Nationalists takeover of the Maritime Customs as well as to the Maritime Customs' continued existence as an institution" (p. 82), a process that was accelerated in areas controlled by Chiang's government during the war.

The challenges of a fragmented polity were managed successfully before the outbreak of an all-out war with Japan in 1937. However, the occupation of China's coastal cities by 1938 and of its central provinces in 1940 led to 'a long-term collapse' of the Nationalists' fiscal policy. The sixth chapter, dedicated to the war period, takes into account the central government resisting Japan but not the collaborationist regimes. The author argues that, until 1940, the KMT fiscal policy "managed to preserve a degree of relative stability" (p. 190), but that changed dramatically from then onwards. An overreliance on tariffs proved difficult to overcome and the KMT fiscal policy did not survive the loss of control over the seaports that had represented 80 per cent of CMC revenue before the war (p. 194). Furthermore, Boecking compares the Chinese central government, Britain, and the Soviet Union during the war and notes that the first "was far less able to rely on foreign loans" (p. 192), with US lend-lease aid to China being significantly lower. Under these adverse circumstances, the Nationalist government developed fiscal instruments, such as interport duty and the wartime consumption tax, recreated from earlier models, notably the lijin (pp. 205-209). The wartime consumption tax delivered "significant amounts of revenue from 1942 until 1944" (p. 210) but was abolished in early 1945, marred by popular resentment and negative impact on trade within unoccupied China.

When the war ended in 1945, the CMC had been transformed. It was subjected to the National Treasury Law in 1942, and Chinese began to replace English as its official language (pp. 221-222). The fact that foreign staff had continued to serve under Japanese occupation led to accusations of collaboration (p. 224, p. 228), which added to further questioning on the legitimacy of their presence. The war years did not just discredit the "association of administrative and technical expertise with the foreignness of the CMC" (p. 225), it also eroded support for the Nationalists. Boecking contends that the "fiscal disintegration of the 
Nationalist state during the war was one of the chief causes of its loss of political legitimacy" (p. 237).

In part, this was connected to the ongoing trade with occupied areas in a murky framework of legality. The Nationalists "neither banned nor licenced this trade" as it created lucrative opportunities for government officials and military officers, with anti-smuggling agencies "in fact engaging in smuggling themselves" (p. 214, p. 230). The author states that Japan allowed the trade with unoccupied China to exacerbate inflation there, although the pursuit of personal profit is very likely to have played a role as well. Indeed, trade and other contacts between occupied and unoccupied China remain relatively understudied. A forthcoming volume by Philip Thai on the role of smuggling as both a challenge to state power and a trigger for repression to assert its authority, spanning from the late Qing to the People's Republic of China (PRC) and including the Second World War period, will no doubt enrich the debate on some of the issues discussed in Boecking's book. ${ }^{5}$

\section{Propaganda and personal connections}

The sometimes-overlooked political importance of personal connections is well explored in News Under Fire. There, Shuge Wei investigates how the Nationalists built the foundations of an international propaganda system before 1941 through a progressively tighter influence over the English-language press. The book is anchored on a variety of primary sources from archives in Taipei, Chongqing, Nanjing, Shanghai, London, Sydney, Yale and the US national archives, as well as several newspapers and published document collections and memoirs. Although other books have focused on Chinese and foreign reporters in wartime China, ${ }^{6}$ this is the first work to explore the links between the treaty-port press and the formation and consolation of a propaganda system by the Nationalist government in the context of the conflict with Japan.

News Under Fire is profusely illustrated by photographs and cartoons by Sapajou, the famous Russian exiled artist who published some of the most iconic images of Republican Shanghai in the North China Daily News. Composed of eight chapters that are divided into three parts, the book combines the study of policymaking and institution building with

\footnotetext{
${ }^{5}$ P. Thai, China's War on Smuggling: Law, Economic Life, and the Making of the Modern State, 1842-1965 (New York, 2018).

${ }^{6}$ E.g. S. R. MacKinnon, China Reporting: An Oral History of American Journalism in the 1930s and 1940s (Berkeley, 1987); P. M. Coble, China's War Reporters: The Legacy of Resistance against Japan (Cambridge, MA, 2015).
} 
discourse analysis of different reports on key events in Sino-Japanese tensions, from the Jinan Incident (1928) to the Mukden Incident (1931) which started the Japanese invasion of the Chinese Northeast, to the occupation of Nanjing (1937). These illustrate the Chinese government's increased ability to make its case to international audiences. Through a careful analysis of several newspapers and the interconnected path of owners, editors, and journalists which produced them, Wei brings to the fore the transnational networks operating in China's treaty ports that brought together Western correspondents and Chinese journalists and politicians, many sharing similar educational backgrounds. Renqing ('human feelings' or 'human relationships') nurtured in the treaty ports were crucial to the institutional development of the Nationalists' international propaganda (p. 254).

One can discern in the central argument of this book a curious parallel to Boecking's analysis of the government's moulding and eventual control of the CMC. Wei argues that in its "propaganda war against imperialist encroachment [from Japan], it was ironically the very product of imperialism - the treaty-port press - that constituted the best resource to connect China with the world press" (pp. 2-3). As with the CMC, accommodation with the liberal treaty-port press was accompanied by government efforts to control and integrate it into its propaganda system. The Chinese government's co-option of the English-language press grew out of its limited options. As the author notes, "China by the late 1920s did not possess a single international news agency, nor did it have full sovereignty over cable transmissions within its own territory" (p. 5), two of the hallmarks of international propaganda systems of major powers.

Nationalist control over the foreign-language press was, however, a process of trial and error. In 1928 the Chinese Ministry of Information set up a division to supervise international propaganda which consisted of a mere editing and translation office (p. 69). In 1930 a 'Registration Order for the Foreign Press' failed because of extraterritoriality (p. 73). Soon, a subtler way was found: the subsidising or purchase of English-language papers, starting from the Peking Leader in 1929. The English-language treaty-port press attracted a wide and influential readership: from Western-educated Chinese intellectuals to foreign diplomats. Many journalists who wrote for treaty-port papers also worked as foreign correspondents for media outside of China (p. 22). If the government wanted its position heard on the international stage, these outlets were crucial. The founding of English-language periodicals by Chinese intellectuals, such as the China Critic, amongst whose long-term editors was Lin Yutang and frequent contributors included Sun Yat-sen's son and then head 
of the Legislative Yuan, Sun Ke (p. 90), also attest to the murky relationship between the state and the press.

Central to Wei's book is the fascinating figure of Hollington Tong (Dong Xianguang). US-educated Tong became the managing editor of the China Press, one of the most influential English-language daily newspapers in Shanghai (p. 146). The importance of personal networks is particularly evident in his case. Here are a few of the many examples of Tong's extraordinary pool of contacts given in the book: at the University of Missouri, where he was the first Chinese graduate from the School of Journalism, he was taught by John B. Powell, who went on to become a long-serving foreign correspondent in China (p. 91); then Tong attended the Pulitzer School of Journalism at Columbia, where he was a classmate of Carl W. Ackerman. In the early 1940s, with Tong as vice-minister of information and Ackerman as dean of the Pulitzer School, "they collaborated to set up a wartime journalism school in China, staffed by Columbia and underwritten secretly by the [American] Office of Strategic Services" (p. 92). But arguably none of Tong's personal connections was more relevant than his acquaintanceship with Chiang Kai-shek. The two men both hailed from the same region and before departing for his studies in America, Tong had been Chiang's high school English-teacher (pp. 146-147). In the early 1930s, Tong responded favourably to requests to "assist with the government's propaganda in Shanghai" (p. 146). Although he later resigned from the paper in the midst of power struggles, Tong was invited to become chief censor of all outgoing press telegrams. The invitation had come from William $\mathrm{H}$. Donald, an Australian journalist, former Times correspondent in China, and member of the board of the China Press, who had become 'unofficial advisor' to Chiang (p. 156). The censorship team Tong organised worked in an office attached to the Military Affairs Commission and was funded by Chiang (p. 157). When the war with Japan broke out in 1937, Hollingtong Tong was appointed to lead the government's centralised international propaganda system. He emphasised the role of personal networks, advising the government "to recruit foreigners to run propaganda operations for China", stressing "the necessity of concealing connections between the government and the information outlets" (p. 187). When he worked in the first wartime capital, Wuhan, Tong was able to largely "withstand the pressure of conservative party propagandists" (p. 202) due to the powerful backing of Chiang and his influential wife, Song Meiling. In contrast, in the second, Chongqing, the Generalissimo "found it preferable to have full authority to curb the spread of certain information that he saw unfit to go public" (p. 225). Personal networks continued to shape Tong's professional operations when he founded the Press Hotel to accommodate foreign 
correspondents with a grant from H. H. Kung (Kong Xiangxi), the powerful Minister of Finance - who would later also fund the reconstruction of the building after it had been damaged in air raids (p. 226, p. 238). Inside the hotel, a post office was installed and the correspondence was monitored by Chiang's intelligence under Dai Li's unassumingly named Bureau of Investigation and Statistics - also known by its abbreviated Chinese name Juntong (p. 227). Tong emerges in the book as an intellectual representative of "the treaty-port elite who had to give up their liberal ideals during a time of national crisis" (p. 254). His post-war career, however, is only briefly addressed. After the war, he returned to the US to study automobile mechanics but was recalled by Chiang to Nanjing in 1947 to return to the international propaganda office. He went on to serve as ambassador to Japan and to the US in the 1950s.

Because its coverage stops in late 1941, Wei's book leaves the reader wanting to know more about the developments of Chinese international propaganda during the later years of the conflict and the Chinese civil war. Whilst the conclusion introduces a curious parallel with the present-day discussions of Chinese soft-power, the topic certainly deserves further scrutiny, for example, by probing into international propaganda initiatives of both the Republic of China and the PRC in the Cold War period and even beyond.

\section{Popular justice}

The sudden end of the Second World War in East Asia brought more uncertainty than conventional narratives allow. For China, Japan's surrender did not exactly mean the end of conflict, with the start (or resumption) of the civil war between the KMT and the CCP erupting soon after. In recent years, the study of the immediate post-war years has received long-overdue attention in the English-language scholarship. An early intervention from a transnational perspective was Margherita Zanasi's article on the Suzhou Trials. ${ }^{7}$ In the meantime, new research projects led to a plethora of publications on post-war justice, with a major work being Barak Kushner's Men to Devils, Devils to Men. It analysed Chinese trials of Japanese accused of class B and C war crimes (conventional war crimes and crimes against humanity), which did not just affect Japanese leaders but also imperial subjects such as the Taiwanese. Exploring the transnational context of Chinese wartime trials, Kushner noted that "public trials of the Japanese were important as a means to promote legal authority

\footnotetext{
${ }^{7}$ M. Zanasi, 'Globalizing Hanjian: The Suzhou Trials and the Post-World War II Discourse on Collaboration', The American Historical Review 113/3 (2008), pp. 731-751.
} 
over domestic justice that also distracted a national discussion about collaboration that had occurred during the Japanese imperial occupation". ${ }^{8}$ However, collaboration did attract considerable attention in post-war China.

Yun Xia's monograph, Down with Traitors, shifts the focus precisely to the hanjian, the "traitors to the Han", offering a comprehensive and multi-faceted analysis of the complicated process of post-war justice in Nationalist China. Similar to the monographs by Boecking and Wei, Down with Traitors is based on multi-sited archival research, conducted in Taipei, Nanjing, Shanghai, Hangzhou and with Chiang Kai-shek's diaries at the Hoover Institution. Periodicals from different Chinese cities are also widely cited. The complexity of the term hanjian and the difficulties of translating it had been noted before, notably by the late Frederick Wakeman, ${ }^{9}$ and Yun Xia provides a detailed analysis of it to explain her option of using the Chinese term throughout the book (except in the catchy book title!).

The scale of the undertaking should be kept in mind: despite the lack of definitive figures, the author notes that it is estimated that while the Nationalist government arrested 2,357 Japanese for war crimes, convicting 442 of them, between 1944 and 1947, 45,679 hanjian cases were processed, 30,185 individuals prosecuted and 14,932 were convicted (pp. 6-7). Yun Xia makes the interesting argument that the government's vague definition of the crime of hanjian and its sanctioning of 'popular vigilantism' in anti-hanjian campaigns paved the way to "state-directed mass movements against perceived internal enemies in the decades to come" (p. 7).

The first chapter traces the origins and evolution of the concept of hanjian and the legal framework for its prosecution before, during and after the war with Japan. It pays special attention to the different regulations on punishing hanjian issued by Chiang's government in the $1930 \mathrm{~s}$ - that influenced anti-hanjian laws in communist base areas (p. 30) - and to the 1945 "Regulations on Handling Hanjian Cases" (reproduced in appendix). The latter not only "provided a legislative framework for post-war trials of hanjian" but also "set up criteria making it easier for the common people to identify hanjian that the judiciary or the intelligence failed to catch" (p. 31). The following chapter details how the violence against these internal enemies sanctioned by the state under the needs of total resistance was pursued in "popular justice and clandestine operations" (p. 46), generating a momentum difficult to

\footnotetext{
${ }^{8}$ B. Kushner, Men to Devils, Devils to Men: Japanese War Crimes and Chinese Justice (Cambridge, MA, 2015), p. 302.

${ }^{9}$ F. Wakeman Jr., 'Hanjian! (Traitor!) Collaboration and Retribution in Wartime Shanghai', in W. H. Yeh (ed.), Becoming Chinese: Passages to Modernity and Beyond (Berkeley, 2000), pp. 298-341.
} 
curb in the post-war era. These secret operations were devised and carried out by KMT intelligence, both the Juntong and paramilitary groups. These practices would make post-war efforts to transferring the trial of hanjian to the civil criminal justice extremely complicated, especially as forms of popular justice continued to be accepted. For example, in August 1946, the Ministry of Justice asked courts to release lists of wanted hanjian so that the public could assist in their arrest (p. 78). This had ambivalent results. According to Xia, whilst it "did help catch many hanjian spies", it "also produced ungrounded charges and unjustified accusations", many a mere expression of "bitter feelings about the war and frustration with a postwar life haunted by inflation, unemployment, instability, and increasing inequality" (p. 79). This was abundantly clear in the trials of economic hanjian. However, as argued in the third chapter, anti-hanjian campaigns "were not restorative in nature" but ended up creating "new channels for government corruption, embezzlement, and nepotism" (p. 80). Confiscation of hanjian assets disproportionally benefited the state, but lack of coordination meant that only part of these found their way into the coffers of the government. The latter did seek to tackle "widespread embezzlement by its officials and employees", with local authorities often keeping part of the frozen hanjian assets and property they were supposed to be guarding (p. 86). As the author notes, "political interference and power struggles impeded justice in the trials of hanjian cases" (p. 111), contributed to public outcry and, in the case of economic collaborators provided good ammunition to criticise the KMT's attitude towards capitalists that had had connections to the Japanese during the war.

Other forms of popular justice are explored in Chapter Four, which addresses cases of individuals labelled cultural hanjian and female hanjian, including well-known writers such as Zhou Zuoren and Eileen Chang (Zhang Ailing). A new genre of anti-hanjian literature emerged in the post-war years. It was disseminated in newspapers and pamphlets and involved the use of gendered verbal violence to denounce those accused of having collaborated or, like Chang, been personally associated (by marriage) with people that did collaborate. Whilst people labelled cultural or female hanjian "were not the primary targets of the state" (p. 113), they became a common object of severe popular criticism, for example through sordid 'hideous histories'.

One of the most original contributions made by Yun Xia's monograph is the attention paid to how the Nationalists sought to punish hanjian whose Chinese identity was either fairly ambiguous or non-existent (in the case of French citizens, for example). In particular, she details the application of the label to people from Taiwan and Vietnam, neither of which was under Chinese sovereignty during the war. The author states that the "policy of including 
overseas Chinese in the anti-hanjian campaigns illustrated the Nationalists' interference with the long-term process of Chinese diaspora" (p. 142) and concludes that "the corruption and abuse of the Nationalists" ended up alienating overseas Chinese (p. 172). More nuance is suggested by some of the examples mentioned in the chapter, which point towards the crucial role played by overseas Chinese themselves in shaping the relationship with the Chinese state. Nevertheless, the tension between local and central government representatives, of corrupt individuals and state actions to tackle issues arising from their actions, could have been unpicked further. How this impacted the Nationalists' links to Chinese communities in Southeast Asia, and how these evolved during the Cold War remains a topic worthy of more research in a comparative perspective. ${ }^{10}$

The afterlives of the concept of hanjian are addressed in the epilogue that looks at the enduring legacy and multiple applications of the term in the PRC, not only under Mao but also up to the present day. This includes a couple of pages on the increasingly nuanced portrayal of hanjian in Chinese films (pp. 182-183), a topic that could certainly be developed into a longer study.

\section{Internationalising Nationalist China at war}

These three books reflect on the impact of China's War with Japan in Nationalist state-building processes as well as on the eventual collapse of their party-state on the Chinese mainland. Although concerned with state institutions, social dimensions (both at the collective and individual level) are not discarded in these studies, be them of CMC IGs, liberal journalists, or those accused of collaboration. Crucially, these books also reveal how profoundly connected to the world China was during the Republican period in general, and the war years in particular.

More than ten years ago, William Kirby stated that "nothing mattered more" for Republican China than its foreign relations, which "defined and shaped" it. ${ }^{11}$ The study of China's War of Resistance has been informed by some attention to international affairs, but only recently have many of its unexplored global links begun to be probed. The three monographs under review demonstrate how histories of domestic politics, economics, media,

\footnotetext{
${ }^{10}$ On the wartime experience of Chinese communities in Southeast Asia see, for example: Lee Y. H., KangRi yu FuRi: Huaqiao, Guomin zhengfu, Wang zhengquan [Anti-Japanese and Pro-Japanese: Overseas Chinese, the National Government, the Wang Regime] (Taipei, 2003); E. Koh, Diaspora at War: The Chinese of Singapore between Empire and Nation, 1937-1945 (Leiden, 2013).

${ }^{11}$ W. C. Kirby, 'The Internationalization of China: Foreign Relations at Home and Abroad in the Republican Era', The China Quarterly, 150 (1997), p. 433.
} 
and justice in China need to consider its transnational connections. In his most recent study of wartime China, Hans van de Ven noted that: "No study of any region during the Second World War should be written without considering its global dimensions". China, as these books confirm, has certainly many worthy of study. ${ }^{12}$

HELENA F. S. LOPES

University of Oxford

12 van de Ven, China at War, p. 12. 